\title{
Repertórios de Saberes e Crenças Afroindígenas em Dalcídio Jurandir ${ }^{1}$
}

\author{
Repertorio de Saberes y Creencias Afroindígenas \\ en Dalcídio Jurandir
}

Repertories of Knowledge and Beliefs

Afroindigenous people in Dalcídio Jurandir

\author{
Agenor Sarraf Pacheco ${ }^{2}$ \\ Jerônimo da Silva e Silva ${ }^{3}$
}

\begin{abstract}
Resumo
O complexo sistema religioso que constitui e orienta vivências, "sensibilidades de mundo (MIGNOLO, 2017)" e posicionamentos sociopolíticos de instituições, grupos e pessoas em territórios amazônicos revela fenômenos de crenças desafiadores para análises monolíticas e monoculturais. Desde o período colonial, os primeiros padres que se estabeleceram na região sentiram embaraços para enquadrar indígenas e depois africanos na ritualística do catolicismo português. Regidos pela incorporação seletiva (WILLIAMS, 1976; CERTEAU, 1998; MARTÍNBARBERO, 2001; HALL, 2003), indígenas e africanos misturaram com maestria elementos de suas religiões com elementos da religião colonizadora. Nessas zonas de contato (PRATT, 2009), para além das formas de estranhamento e violência, emergiram traduções culturais em práticas de afetamento de lá e de cá, sociabilidades e complementaridades, gestando repertórios de religiões de matriz afroindígena em territórios da diferença colonial (MIGNOLO, 2013) que desestabilizaram padrões e normas da teologia cristã ocidental. Neste trabalho, mergulhamos em experiências religiosas interculturais comungadas por indígenas e africanos em zonas de contato na Amazônia sob o olhar da produção literária do romancista paraense e marajoara, Dalcídio Jurandir (19091979). Procuramos cartografar em romance deste literato, repertórios de saberes, fazeres e crenças afroindígenas para reconstituir complexas tramas do fenômeno religioso em nossa densa e extensa região. Para o alcance da proposta, embarcaremos na canoa dos Estudos Culturais, Pós-Coloniais e Decoloniais por intermédio
\end{abstract}

\footnotetext{
${ }^{1}$ A versão preliminar do artigo foi apresentada no Simpósio Temático 05 - Fronteiras Culturais em Contextos Epistêmicos Descoloniais II, durante o II Seminário Latino-Americano de Estudos em Cultura - SEMLACult em Foz do Iguaçu/PR, Brasil, 2018. Pesquisa financiada pela Coordenação de Aperfeiçoamento de Pessoal de Nível Superior - CAPES, com bolsa de Pós-Doutorado PNPD/2018-2019, em desenvolvimento no Programa de PósGraduação em Dinâmicas Territoriais e Sociedade na Amazônia, na Universidade Federal do Sul e Sudeste do Pará (PDTSA/UNIFESSPA).

${ }^{2}$ Doutor em História Social pela PUC-SP. Professor Associado I da Universidade Federal do Pará. Belém, Pará, Brasil; sarrafagenor@gmail.com

${ }^{3}$ Doutor em Antropologia pela UFPA. Professor Adjunto III da Universidade Federal do Sul e Sudeste do Pará. Marabá, Pará, Brasil; jero1978@unifesspa.edu.br
} 
da Cartografia para repertoriar essas práticas culturais nas interfaces de teorias e metodologias nômades que combatem convenções do pensamento moderno que separou ciência de religião, sagrado de profano, natureza de cultura, oral de escrito, entre outras abissalidades e formas de vida e de luta que não são puras, pois tradições são sempre reinventadas e etnicidades historicamente misturadas.

Palavras-Chave: Religião; Literatura; Cartografia; Decolonial; Afroindígena.

\title{
Resumen
}

El complejo sistema religioso que constituye y orienta vivencias, "sensibilidades de mundo (MIGNOLO, 2017)" y posicionamientos sociopolíticos de instituciones, grupos y personas en territorios amazónicos revela fenómenos de creencias desafiantes para análisis monolíticos y monocultura. Desde la época colonial, los primeros sacerdotes que se establecieron en la región sintieron vergüenza para enmarcar y luego los africanos indígenas en el catolicismo ritual portugués. En el caso de los indígenas, los indígenas y los africanos mezclaron con maestría elementos de sus religiones con elementos de la religión colonizadora. En estas zonas de contacto (PRATT, 2009), además de las formas de extrañamiento y violencia, surgieron traducciones culturales en prácticas de afectación de allí y de acá, sociabilidades y complementariedades, gestando repertorios de religiones de matriz afroindígena en territorios de la diferencia colonial (MIGNOLO, 2013) que desestabilizaron patrones y normas de la teología cristiana occidental. En este trabajo, nos sumergimos en experiencias religiosas interculturales comunales por indígenas y africanos en zonas de contacto en la Amazonia bajo la mirada de la producción literaria del novelista paraense y marajoara, Dalcídio Jurandir (19091979). Buscamos cartografiar en romance de este literato, repertorios de saberes, haceres y creencias afroindígenas para reconstruir complejas tramas del fenómeno religioso en nuestra densa y extensa región. Para el alcance de la propuesta, embarcaremos en la canoa de los Estudios Culturales, Postcoloniales y Decoloniais por intermedio de la Cartografía para repertoriar esas prácticas culturales en las interfaces de teorías y metodologías nómadas que combaten convenciones del pensamiento moderno que separó ciencia de religión, sagrado de profano, la naturaleza de cultura, oral de escrito, entre otras abisalidades y formas de vida y de lucha que no son puras, pues tradiciones son siempre reinventadas y etnicidades históricamente mezcladas.

Palabras claves: religión; literatura; cartografía; descoloniales; Afroindígena.

\begin{abstract}
The complex religious system that constitutes and guides experiences, "world sensibilities" (MIGNOLO, 2017) and socio-political positions of institutions, groups and people in Amazonian territories reveals phenomena of challenging beliefs for monolithic and monocultural analyses. Since the colonial period, the first priests who settled in the region felt embarrassed to fit indigenous and then African people into the ritualistics of Portuguese Catholicism. Regulated by selective incorporation (WILLIAMS, 1976; CERTEAU, 1998; MARTÍNBARBERO, 2001; HALL, 2003), indigenous and African people masterfully mixed elements of their religions with elements of colonizing religion. In these areas of contact (PRATT, 2009), in addition to the forms of estrangement and violence, cultural translations emerged in practices of affection from there and here, sociabilities and complementarities, managing repertoires of religions of African-indigenous matrix in territories of colonial difference (MIGNOLO, 2013) that destabilized standards and norms of Western Christian theology. In this work, we delve into intercultural religious experiences shared by indigenous and African people in contact zones in the Amazon under the gaze of the literary production of the novelist from Pará and Marajoara, Dalcídio Jurandir (19091979). We try to map in this writer's novel, we sought to map out repertories of AfroIndigenous knowledge, deeds and beliefs to reconstitute complex plots of the religious phenomenon in our dense and extensive region. To reach this proposal, we will embark on the canoe of Cultural, Post-Colonial and Decolonial Studies through Cartography to repertoire these cultural practices in the interfaces of nomadic theories and methodologies that combat conventions of modern thinking that separated science from religion, sacred from profane, nature of culture, oral from written, among other abyssalities and forms of life and struggle that are not pure, because traditions are always reinvented and ethnicities historically mixed.
\end{abstract}

Keywords: Religion; Literature; Cartography; Decolonial; Afroindigenous. 


\section{Introdução}

O complexo sistema religioso que constitui e orienta vivências, sensibilidades de mundo (MIGNOLO, 2017) e posicionamentos sociopolíticos de instituições, grupos e pessoas em territórios amazônicos revela fenômenos de crenças desafiadores para análises monolíticas e monoculturais. Desde o período colonial, os primeiros padres que se estabeleceram na região sentiram embaraços para enquadrar indígenas e depois africanos na ritualística do catolicismo português.

Regidos pela incorporação seletiva (WILLIAMS, 1976; CERTEAU, 1998; MARTÍN-BARBERO, 2001; HALL, 2003), indígenas e africanos misturaram com maestria elementos de suas religiões com elementos da religião colonizadora. Nessas zonas de contato (PRATT, 2009), para além das formas de estranhamento, dominação, violência, hierarquia, emergiram traduções culturais em práticas de afetamento de lá e de cá, sociabilidades e complementaridades, gestando religiões de matriz afroindígena em territórios da diferença colonial (MIGNOLO, 2013) que desestabilizaram padrões e normas da teologia cristã ocidental. Não por acaso, a forte perseguição e o preconceito contra pajés, pais de santo, adivinhos, exorcistas, entre outros, no período colonial ainda hoje compõem o imaginário das religiões hegemônicas em renitentes práticas de intolerância de norte a sul no Brasil (SILVA, 2014).

Marcio Goldman (2015, p. 645) em diálogo com Roger Bastide (1976 [1973], p. 32) observou que a literatura especializada sobre religiões no Brasil pouco enfrentou o "encontro e casamento dos deuses africanos com os espíritos indígenas". Quando isso ocorreu, o ponto de vista dominante foi o do "branco europeu", deixando nas sombras a capacidade de afros e indígenas agenciarem e recriarem, em imprevisíveis criatividades, seu complexo sistema de crenças, costumes e tradições (DELEUZE e GUATTARI, 1995; GLISSANT, 2005; WAGNER, 2012).

Intelectuais de ponta e de peso como Manuel Nunes Pereira, Arthur Cezar Ferreira Reis, Vicente Salles, Marcos Carneiro de Mendonça, Antonio Carreira, Anaíza VergolinoHenry e Arthur Napoleão Figueiredo, Rosa Elizabeth Acevedo Marin, primeiros estudiosos da presença negra na Amazônia, e depois Flávio dos Santos Gomes, Rafael Chambouleyron, Patrícia Sampaio, Agenor Sarraf Pacheco, entre outros, centraram suas preocupações em visibilizar o "enegrecimento das paisagens humanas" nesta parte norte do Brasil. Esses intelectuais, duvidando do "vazio humano africano", enfrentaram percepções apressadas e restritas de estudiosos nacionais e internacionais que procuraram reforçar o mito da 
“Amazônia: Terra de Índio", "paraíso isolado e parado no tempo”, por não se enquadrar no modelo da plantation verificada no centro-sul do país.

Assim, a constituição das religiões de matriz afroindígena em circuito marajoara fezse em práticas e saberes de tradições orais (HAMPATÉ BÂ, 2011) com nações indígenas e a presença negra (PEREIRA, 1952; SALLES, 2005 [1971]; SARRAF-PACHECO, 2009). Neste contexto, interessado em mergulhar nas experiências religiosas interculturais comungadas por indígenas e africanos em zonas de contato na Amazônia sob o olhar da produção literária do romancista paraense e marajoara, Dalcídio Jurandir ${ }^{4}$, procuramos cartografar repertórios de saberes em práticas de cura em territórios de religiões afroindígenas na Amazônia.

A escolha por trabalhar romances que compõem o chamado Ciclo do Extremo-Norte de Jurandir justifica-se por sua ambientação em plurais realidades Amazônicas, seja em paisagens do norte ou do sul da região, em áreas de florestas, campos e cidades, as quais permitem reconstituir complexas tramas do fenômeno religioso de matriz afroindígena em nossa densa e extensa região. Apreendemos esses territórios amazônicos na perspectiva de um "pensamento arquipélago e fronteiriço" (GLISSANT, 2005; HALL, 2003) preocupado com a emergência de "histórias alternativas" (MIGNOLO, 2003) paridas em fronteiras liminares, as quais levam em conta e procuram valorizar os outros das histórias ocultas e suas potencialidades não apenas físicas, mas também cognitivas, inventivas e espirituais.

Assim, no mapeamento de nomes e trabalhos de literatos brasileiros, sejam eles romancistas ou cordelistas, estudados por pesquisadores da Teopoética (CANTARELA, 2014), não encontramos nenhum trabalho focalizando os eixos "Religião, Literatura e Práticas Afroindígenas" para apreender o afroindigenismo que vem se revelando como plasmador de um modo amazônico, brasileiro e latino-americano de estar no mundo. Do ângulo de nossa enunciação como descendente de judeus na Amazônia que se esparramaram por pluriversos territoriais marajoaras no espocar do século XIX, "somos alinhavados em nossas cosmologias cotidianas pelos conhecimentos do mundo indígena e africano em profundas interconexões" (SARRAF-PACHECO, 2012, p. 200).

\footnotetext{
${ }^{4}$ Dalcídio Jurandir nasceu em 10 de janeiro de 1909, na vila de Ponta de Pedras, arquipélago de Marajó, e faleceu no dia 16 de junho de 1979, no Rio de Janeiro. Durante sua trajetória escreveu onze romances, 10 deles compõem aquilo que denominou de Ciclo do Extremo Norte. São eles: Chove nos campos de Cachoeira (1941), Marajó (1947), Três casas e Um Rio (1958), Belém do Grão-Pará (1960), Passagem dos Inocentes (1963), Primeira Manhã (1967), Ponte do Galo (1971), Chão dos Lobos (1976), Os Habitantes (1976) e Ribanceira (1978).
} 
No cartografar de uma historiografia do afroindigenismo no Brasil desde a Amazônia, uma diversidade de pesquisas tem se enveredado por temáticas da linguagem, etnicidade, religiosidade, saberes, fazeres, formas de habitar, pensar, compartilhar, lutar e construir a existência física e espiritual dentro de outros padrões de identificação, cuja matriz nem sempre é étnica, mas sociopolítica. "A compreensão desse processo, contudo, não é negar as tradicionais identidades culturais com as quais os habitantes da região operam para falar de si, de sua história e cultura, mas abrir brechas nos discursos essencialistas e guetizadores sobre identidade". Nestes quadros, "apostamos na existência de uma dicção afroindígena, assim como em performances, vocábulos, culinárias, estéticas, crenças, costumes e tradições que diferenciam a constituição de homens, mulheres e crianças amazônidas, quando se apresentam em ambientes intersticiais" (SARRAF-PACHECO, 2012, p. 200).

Para interpretar territorialidades de narrativas de religiões/religiosidades de matriz afroindígena na Amazônia, partimos de Dalcídio Jurandir, um dos maiores romancistas brasileiros, na percepção de seus principais estudiosos e críticos literários como Marli Furtado, Willi Bolle, Gunter Karl Pressler, Paulo Nunes, Olinda Batista Assmar, para citar os principais.

Sobre o lugar e importância de documentos literários e poéticos como poderosos acervos de leitura de realidades humanas e não-humanas em interstício, Antônio Cândido defende a literatura como uma indispensável chave de leitura da experiência social e "forma de pesquisa e descoberta do país" (CANDIDO, 1981, p. 112). Por esse ângulo, na percepção de Willi Bolle (2011, p. 44), ler os romances do Ciclo do Extremo Norte de Dalcídio Jurandir permite um mergulho no "conhecimento da Amazônia no século XX", centrando-se em territórios de "Belém, Marajó e do Baixo Amazonas", traz as interrelações do oral com o escrito, do sagrado com o profano, da injustiça com a justiça, do bem e com o mal, como dimensões amalgamadas da vida material e simbólica, na contramão de abissalidades exercidas pela epistemologia ocidental racionalista (SANTOS, 2010).

A despeito do rico acervo acadêmico e da fortuna crítica que a obra de Jurandir tem produzido nas três últimas décadas, no que tange a relação religião, literatura e território, até o presente momento, identificamos apenas a dissertação de mestrado "Do Dilúvio à Vida: Chove nos Campos de Cachoeira", de Sandra Terezinha Perlin (2013) e o projeto de mestrado, "Belém do Grão-Pará: análise dos aspectos religiosa na literatura de Dalcídio Jurandir", de Daniela dos Santos Brandão (2016), vinculados ao Mestrado em Ciências da 
Religião, da Universidade do Estado do Pará (UEPA), sob a orientação do Prof. Dr. Douglas Rodrigues da Conceição.

Considerando a importância do conceito de território nesta pesquisa, o apreendemos como um espaço de encontros, construções, mediações, disputas, negociações, sociabilidades e interculturalidades sem fronteiras fixas, podemos concordar com a assertiva de Rodrigo Vidal (1997) de que toda prática política, cultural e social se traduz numa "produção territorial". Os territórios são elaborações de mulheres e homens a partir de seus desejos e necessidades em ambientes de concretudes simbolizadas e significadas em representações carregadas de sentidos da existência.

O território, comenta Vidal (1997), é produzido dentro de um sistema cultural e, acrescentaríamos, sempre aberto e movente, mas que se projeta, segue o autor, como uma prática cultural que acontece em espaços terrestres. Nesse entendimento, ampliaremos esses espaços para o aquático, sideral, invisível, onde a relação de homens e mulheres com o sagrado deita longo intercâmbio, entendimento e historicidade. Uma profunda relação afetiva entre o humano e o não-humano com o planeta terra e outros habitares visibiliza-se. Ao longo do estágio de pós-doutoramento, pretendemos mergulhar na literatura especializada sobre as potencialidades e problemáticas do campo do território como lugares praticados para apreender evidencias de narrativas escritas e orais sobre religiões de matriz afroindígena na Amazônia.

Frente ao exposto, a preocupação em cartografar a dimensão religiosa seja ela de tradição cristã ou de tradição oral afroindígena na saga romanesca dalcidiana faz-se necessária. Entendemos por religiões de matriz afroindígena o cruzamento entre o pluriversal mundo dos encantados, caruanas e o mundo dos orixás, voduns e inquices, sem esquecer, do ponto de vista afroindígena, a incorporação de santos do catolicismo popular e práticas do espiritismo, assim como os novos sentidos espirituais que passaram a ganhar entidades em celebrações afroindígenas (MAUÉS, 1995; PRANDI, 2006; SARRAF-PACHECO, 2009; SILVA, 2014).

Em radiografia produzida por Cantarela (2014) sobre pesquisas em Teopoética, apreendemos que a maioria dedicou atenção ao estudo da Bíblia ou a obras de filósofos e literatos europeus, latino-americanos, africanos ou de literatos brasileiros. O esforço do pesquisador em repertoriar à exponencial produção acadêmica no Brasil na interface religiãoliteratura, nas últimas décadas, incentiva exploramos outros literatos, literaturas e temáticas fundamentais à compreensão de diferentes realidades sociais brasileiras. Para Serry (2004, p. 129), "tentar compreender as relações da religião e da literatura é trazer à luz a sociogênese de 
dois sistemas de crenças, cujas lógicas próprias partilham um poder similar de ordenar o mundo".

Nesses mundos cruzados do "fato religioso com o fazer literário" (CANTARELA, 2012b, p. 5) para sondar cosmologias indígenas e africanas em fusões no cenário amazônico, a problemática que procuraremos responder neste artigo é: Que narrativas, práticas e saberes de religiões de matriz oral afroindígena emergem em produções literárias dalcidianas ambientados no arquipélago de Marajó? Qual o lugar dessas práticas e saberes no entendimento do ethos humano na região amazônica? Que representações do sagrado permitem adentra dimensões do simbólico, seus sentidos e sensibilidades de mundo nos rituais da vida dos personagens que emergem de escrituras e oralidades deitadas no papel?

Discutir as interrelações religião e literatura, religiões de matriz afroindígena para em seguida explorar os repertórios de saberes e crenças afroindígenas na pena dalcidiana é o caminho cartográfico que o enredo do artigo percorre a partir de agora.

\section{Religião e Literatura}

Na última década, temos nos dedicado a estudar experiências socioculturais e práticas de religiosidade popular de tradição oral e devocional de populações marajoaras, atentando especialmente para o cotidiano dos modos de acreditar, festejar, trabalhar e lutar pela existência física e espiritual (SARRAF-PACHECO, 2004; 2009). Sem recortes temporais definidos, mas partindo de inquietações do presente, as pesquisas no campo da História em interfaces com a Antropologia Pós-Moderna, fundamentadas nos Estudos Culturais Britânicos, Latino-americanos, Pós-Coloniais e Decoloniais (HOGGART, 1973; WILLIAMS, 1979; HALL, 2003; QUIJANO, 1992; MIGNOLO, 2003; GLISSANT, 2005; LANDER, 2005) tem permitido indagar relatos de crônicas, viajantes, literatos, jornalistas e outros narradores sobre os modos de vida e de luta no maior arquipélago flúvio-marinho do mundo. A ênfase tem sido dada ao entendimento da presença de poderes eclesiásticos portugueses e espanhóis em permanentes contatos, querelas e negociações com religiões de matriz oral afroindígena (SARRAF-PACHECO, 2010).

Semelhante a outras tempos e lugares, na Amazônia as religiões sejam elas alinhadas à colonialidade ou à decolonialidade orientam a vida de mulheres e homens de traços multiétnicos e condições socioeconômicas distintas. Nesse circuito da cultura, Dalcídio Jurandir ao fazer-se voz contra antigas e renovadas práticas de colonialismo, compõe poderosa estética literária, valorizando saberes e fazeres de outros sistemas de crenças em 
meio a presença de grupos e instituições de poder, defensores da religião oficial. Nestes quadros, o repertório de narrativas do romancista emerge em "desobediências epistêmicas" (MIGNOLO, 2008) com códigos canônicos e eruditos, numa atitude poética e política de contaminar o escrito nas sonoridades, ritmos, performances e estéticas do oral, trazendo à cena outras histórias, memórias, saberes e religiosidades em suportes do letramento ocidental e modernizante (ANTONACCI, 2001).

Dalcídio Jurandir nasceu no arquipélago de Marajó, filho de uma mãe negra com um pai descendente de português de classe baixa. Ao longo de sua trajetória, ele sofreu influências do pensamento de esquerda marxista leninista e humanista e recriou à luz da cultura de sua gente miúda e das canoas, um projeto de literatura que primava, além de outros aspectos, pela denúncia das injustiças sociais no mundo amazônico. Na compreensão de Willi Bolle (2001, p. 3), Dalcídio "renovou com sua obra a imagem literária da Amazônia". Ultrapassando as representações míticas, lendárias e a preponderância das florestas, águas e animais, o romancista deu centralidade ao drama humano, psicológico, religioso e social vivido em território de uma profunda "semântica das contradições históricas, políticas e econômicas" (PRESSLER, 2010, p. 236). A perspectiva de Jurandir abdica do regionalismo fechado em si para fazer-se universal. Ao recompor a angústia que constrói e destrói o humano em diferentes temporalidades e territorialidades, o romancista "mesmo usando o belo pano de fundo da Amazônia paraense e todos os seus mistérios, não se preocupou em falar do suposto homem (e da mulher) daqui e sim de todo e qualquer ser humano que tem na angústia do viver a sua única e mutante existência” (LOUREIRO, 2015).

As inter-relações entre literatura e religião em territorialidades construídas e significadas, em outras palavras, "entre o fazer teológico e o fazer literário", ultrapassam fronteiras disciplinares. No balanço preliminar realizado por Cantarela (2014, p. 1246) identifica-se

uma imprecisão de limites entre o discurso literário, objeto da fruição estética e da crítica literária, e o discurso religioso, objeto da fruição religiosa e da teologia. O texto literário não se oferece como objeto de leitura apenas à crítica literária, assim como o texto de caráter religioso não se reduz a mero objeto de estudo da teologia. (...) a literatura, ao "redescrever" o mundo com seu poder heurístico, se oferece como fértil terreno para a teologia.

Conceição (2013), por sua vez, salienta a necessidade de preservarmos a crítica à religião cristã presente no texto literário para deixar vir à tona percepção de outras teologias que se libertem das hermenêuticas eclesiásticas e dogmáticas. Assim, um exercício de leitura atenta nos romances "Chove nos Campos de Cachoeira", "Marajó", "Três Casas e Um Rio" e 
"Ribanceira" ao ser cruzada com pesquisa histórica e antropológica certamente abrirá um leque de possibilidade de interação e interpretação com as teologias de matriz oral afroindígena na região amazônica, com destaque para o arquipélago de Marajó.

O filósofo e antropólogo, Edilson Pantoja da Silva, estudioso da obra dalcidiana assinala que

A maioria dos personagens de Jurandir, no entanto, transita na esfera religiosa: rezadores de ladainhas, promesseiros, devotos, guardas de santos, membros de irmandades... Trata-se, contudo, de uma religiosidade unilateral, mantida somente pelo milagre humano de todo sonho, querer e desejar vida melhor, e, nisto, produzir manifestações como são, por exemplo, as festas dedicadas a padroeiros de vilas e cidades, que o escritor soube tão bem mesclar à vida vivida de seus personagens (SILVA, 2015, p. 432).

Neste contexto, a polifonia do texto literário, religioso e filosófico abre portas para garimparmos uma multiplicidade de experiências sociais e seus sentidos. Considerando a inserção de Dalcídio Jurandir no circuito do romance de crítica social que pipocou no Brasil a partir dos anos de 1930, a grande maioria de seus personagens tecem sinuosos modos de estar, acreditar e construir relações socioculturais e conflitivas no e com o mundo. Para Silva (2015, p. 1) não é possível enrijecer o campo da linguagem que açambarca religião e literatura. “As tradições religiosas judaico-cristãs nascem literariamente; que a literatura pode criar um homem livre das interpretações dogmáticas das instituições cristãs sem desconsiderar o elemento religioso; e que os textos literários podem estar sempre abertos a novas interpretações, mesmo quando em diálogo com os textos ditos sagrados". Em outra direção, Galvão (2006, p. 1-2) argumenta que

Nosso pensamento social constituiu-se às voltas com nossa formação pluriétnica e com a mestiçagem, reflexão que se reconhece em seu próprio cerne. Por isso, a crítica literária brasileira vê-se, amiúde, obrigada a recorrer aos estudos de religião para não desfigurar seus objetos: poucas literaturas do mundo estarão tão impregnadas da presença de diferentes hibridismos religiosos.

Perlin (2013) partindo do entendimento de que as escrituras sagradas são basilares na gestação das literaturas ocidentais, mapeou no romance "Chove nos Campos de Cachoeira", elementos bíblicos afetados e em consonância com a vida marajoara. Neste exercício hermenêutico da linguagem religiosa, o simbolismo da água e do fogo atravessa diferentes agentes em suas práticas e saberes culturais. O romance traz, então, "um mundo de campos queimados, (...) que além de encharcados, continha também um mundo de ardidos e chamuscados pelo fogo, delineados no texto dalcidiano, a partir da força simbólica das imagens" da água e do fogo (PERLIN, 2013, p. 10). 
Na compreensão de Edilson Pantoja da Silva, as construções romanescas de Dalcídio Jurandir exploram, entre outros temas, o "desviver", porque a "aristocracia de pé no chão", como apreende o literato as gentes pobres das canoas, fazendas, roças, sítios, pesqueiros, espalhadas pelo vasto território marajoara, existem em presença de situações físicas, psicológicas e espirituais atravessadas pela negação da vida.

Tal radicalização ocorre na medida em que os "aristocratas", a quem Jurandir dedicou os dez volumes, vivem sofrimento sem solução - salvo a da morte. Para tais personagens, a vida é um "desviver", como expressa a filha do Cristo Seruaia, personagem de Ribanceira (Jurandir 1978: 317). Na série, vasta galeria dos que "desvivem", ninguém encontra saída, a começar por Eutanázio, grande nome de Chove, figura-mor de todos os outros. Nem mesmo Alfredo, protagonista de nove romances (...), que percorre o conjunto em busca de transcender sua condição, encontra solução (SILVA, 2015, p. 432).

A obra literária ao reconstituir as condições de vida a que estão submetidos a maioria dos personagens dalcidianas, igualmente as dimensões do sagrado, questiona ortodoxias da matriz judaico-cristã e permite combinações entre arte, filosofia, religião, história, antropologia (MAGALHÃES, 2009; SPERBER, 2011; CONCEIÇÃO, 2013; SILVA, 2008; SILVA, 2015), para conhecermos outros modos de acreditar, celebrar, festejar e simbolizar a vida. Por esses termos, ela provoca reflexões, tomadas de atitude e combate ao controle do desenvolvimento livre do ethos religiosos de cada ser humano. É possível lembrar, no entanto, que "a análise dos vínculos entre literatura e religião não pode se contentar com uma análise da produção como tal, mesmo relacionada ao contexto. Ela requer uma reconstrução do quadro sociohistórico das relações dessas duas realidades sociais” (SERRY, 2004, p. 149). O centro da relação entre literatura e religião ou "os múltiplos intercâmbios entre o vocabulário da arte e o vocabulário sacramental” está em seu caráter transcendental, porque implode com “o domínio da causalidade, do explicável. Em outras palavras: que escaparia a toda racionalidade exterior" (SERRY, 2004, p. 129).

Nestes quadros, Conceição (2012, p. 40) em diálogo com Paul Tillich (2001) defende a compreensão da religião como lugar onde se experimenta o incondicionado. "É no seu interior que a fé se apresenta como o estado em que se é possuído por algo que nos toca incondicionalmente". Em última instância, homens e mulheres que se orientam pela dimensão espiritual tem em Deus, santos, encantados ou orixás, a maior preocupação de sua existência física e simbólica. 


\section{Religiões de Matriz Afroindígena}

Os estudos que se debruçaram sobre o campo religioso na Amazônia, especialmente nas áreas de História e Antropologia, constituíram duas perspectivas interpretativas sobre os modos de crer, trabalhar e viver na região. De um lado, encontramos trabalhos centrados especialmente no indígena com seus deuses, caruanas e encantados, conformando o campo da etnologia indígena; e de outro lado, localizamos pesquisas com foco no negro africano ou afroamazônico com seus orixás, voduns, inquíces, constituindo o campo das religiões de matrizes africana na região. A preocupação com as zonas intersticiais onde homens e mulheres etnicamente diferenciados misturaram costumes, crenças, lutas por liberdade e pela existência tem recebido pouco investimento acadêmico.

Trabalhos focados nas zonas de mestiçagem, em linhas gerais, trouxeram à tona os modos de constituição do caboclo da Amazônia, categoria complexa, multifacetada, polêmica e pouco esclarecedora sobre a visibilidade das interações étnico-raciais. De acordo com Gandon (1997, p. 135), “a presença do índio na mestiçagem do povo brasileiro, bem que nitidamente visível, permanece como uma ficção, o caboclo sendo muitas vezes percebido apenas como imagem ideológica - o que é sem dúvida um dos seus aspectos - como entidade etérea, ou como figura lendária". A visibilidade da cor do branco e do negro não visibiliza a cor do caboclo. Já Véronique Boyer (1999, p. 30) em pesquisa sobre o pajé e o caboclo, situando sua experiência etnográfica na cidade de Belém aponta que, em linhas gerais, o termo caboclo carrega sentido negativo. Ele refere-se ao morador do espaço rural, "crédulo e idiota".

Enquanto alguns estudiosos se dedicaram à defesa e/ou à crítica ao termo caboclo (SILVA FILHO, 2011), outros alinharam-se a perspectivas dos estudos indigenistas ou afrobrasileiros, seja para analisar trajetórias históricas ou modos de vida, seja para compreender religiões de matriz oral indígena ou africana. Ao investirem esforços para ler na documentação oficial presença e agência de indígenas ou negros, atentos em boa medida nas “dualidades índios/brancos ou negros/brancos" (ARRUTI, 2001, p. 217), os pesquisadores recortaram as teias de relacionalidades ou conflitualidades costuradas por esses grupos étnicos em luta por sua existência e reprodução física, simbólica e espiritual em diferentes estados brasileiros.

Stuart B. Schwartz ao investigar uma nova tentativa de revolta em defesa da liberdade promovida por escravos haussás muçulmanos em tempos de insurreições escravas na Bahia, no correr de 1814, deixa ver como "as comunidades quilombolas locais, que 
incluíam alguns caboclos e índios, foram incorporadas no plano de revolta" (SCHWARTZ, 2003, p. 13). O pesquisador norte-americano narra que a presença das populações indígenas no movimento dos escravos da diáspora africana em Salvador poderia lhes garantir a reconquista das terras sob a custodia dos portugueses. Mesmo que suas visibilidades fossem incomuns na vida soteropolitana de uma capital que se enegrecia ao longo de sua história, os indígenas estavam visibilizados nas lutas dos insurretos negros. Apesar das zonas de intersecção entre indígenas e negros da diáspora ao longo da história do Brasil e da Amazônia terem sido alinhavadas desde o período colonial, com pesar o autor comenta que pouco sabemos "o que os negros e os indígenas pensavam, uns sobre os outros". E tornou-se "difícil de desvendar, já que a documentação sobre o relacionamento mútuo é esparsa e sempre filtrada pelo olhar atento dos colonizadores" (SCHWARTZ, 2003, p. 14).

O exercício da crítica documental permite dizer que se as pistas do passado são politicamente produzidas com vigilância e jogos de interesses, não menos complexas eram as estratégias inventadas pela coroa portuguesa para criar climas hostis entre indígenas e negros. A complexidade dessas relações expressa-se nas posições e papeis que esses agentes históricos assumiam na organização do vigiado cotidiano colonial. A despeito disso, "a condição comum de oprimidos e despossuídos contribuía inexoravelmente para aproximá-los. Um testemunho da época colonial diz que os índios tanto podiam ser os melhores aliados dos negros como os mais eficazes caçadores de escravos fugitivos" (GANDON, 1997, p. 140).

Se a Bahia se tornou conhecida como o mais forte território da negritude brasileira, os intercâmbios entre indígenas e negros na história do litoral norte deste estado não ficaram sem registro. Em pesquisa acerca deste estado, Gandon defende que os interstícios físicos e culturais gestados por esses dois grupos humanos deixaram "traços marcantes nos corpos, na língua, nas práticas - cotidianas e festivas - na religiosidade, no imaginário e nas expressões artísticas de uma vasta área" (GANDON, 1997, p. 138).

Pelo ângulo das práticas religiosas, Jerônimo Silva (2014) depois de resenhar trabalhos de diversos historiadores e antropólogos sobre as religiões de matriz indígena e africana como a pajelança, a Mina, a Jurema, o Catimbó, a Umbanda, o Candomblé, entre outras, sem negar especificidades, apreendeu pontos de conexão entre cosmologias indígenas e africanas em ambientes migrantes e da diáspora. Com base nessa compreensão, o pesquisador interagiu e procurou compreender sentidos do viver, acreditar, fazer e estar no mundo de diferentes mulheres e homens que se deslocaram, na segunda metade do século XX, do nordeste brasileiro para a região bragantina no Pará. Assim, no veio de "memórias de pajés, mães e pais de santo, rezadeiras e exorcista", reconstituindo lutas históricas que 
"remetem a massacres de populações indígenas e de origem africana, fugas e revoltas de migrantes ou descendentes de cearenses, piauienses e paraibanos" (SILVA, 2014, p. 48), o pesquisador "intuiu o trânsito das entidades de religiões ameríndias e africanas a partir de processos migratórios e crenças em suas ancestralidades" (SILVA, 2014, p. 53). Neste contexto, insere-se a entidade Tupinambá, defensor do trapiche do Moconha em Melgaço, no arquipélago de Marajó. Historicamente convencionou-se pensar a representação dessa entidade como um indígena, alto, forte e valente guerreiro. Contudo, sua descrição física e seus poderes sobrenaturais, narrados por Dona Celeste, pajé da cidade e mãe da corrente da encantaria, indicam mesclas de culturas indígenas e africanas na constituição das identidades marajoaras (SILVA e SARRAF-PACHECO, 2012).

Já Vanzolini (2014, p. 271), por exemplo, ao estabelecer relações “entre modos de fazer e pensar a feitiçaria num contexto ameríndio e em algumas casas de religião de matriz africana no Brasil", sugere que pelas intersecções dos pluriversos do "axé" e do "perspectivismo ameríndio" emerge um "pensamento afroindígena" em contraposição às formas como interpretamos a realidade sócio-espiritual vivida no ocidente. Observando "os limites analíticos e teóricos da polarização, corrente na literatura de ciências sociais no Brasil, entre os classificadores 'raça' e 'etnia'”, em outras palavras entre indígenas e negros, Arruti (1997, p. 7), por sua vez, sugere pensarmos em uma "plasticidade identitária" para a construção de novas etnicidades e invenções culturais produzidas por esses dois grupos humanos, uma vez que nos últimos tempos "produção científica, criação jurídica e ação política" têm se tornado ações contínuas para trazer à tona histórias, lutas, dificuldades e conquistas de direitos sociais por indígenas, negros e quilombolas.

Em 2012, quando Jerônimo da Silva iniciou suas pesquisas de doutorado em Antropologia na Universidade Federal do Pará, seguindo rastros da metodologia da História Oral, através de entrevistas com diferentes moradores da chamada região bragantina, no Pará, contando com minha parceria nas reflexões da investigação em curso, mapeou discursos midiáticos, religiosos e dos habitantes do lugar sobre possessões coletivas ocorridas com

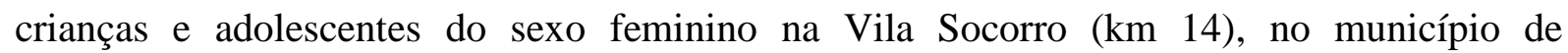
Traquateua (PA). Com isso, trouxe à tona sentidos dessas possessões, desvelando matrizes de religiosidades indígenas e africanas na Amazônia Bragantina. Frente aos acontecimentos e estranhamentos, o pesquisador acompanhou os rituais de exorcização realizados pelo jovem xamã Cristiano que, ao operar com poderes do Caboclo Flechador, frente a entidades incorpóreas, mortos-vivos e demônios, desvelou memórias que povoam corpos e dons espirituais emergentes no seio das populações locais. Nossa compreensão foi que a avaliação 
apressada dos acontecimentos como "fenômenos sobrenaturais" pelos meios de comunicação silencia tradições de culturas afroindígenas neste portal da Amazônia brasileira (SILVA e SARRAF-PACHECO, 2012).

Já em 2015, após a conclusão do doutorado, o pesquisador retomou exercícios etnográficos construídos ao longo do mestrado em Comunicação, Linguagens e Cultura na Universidade da Amazônia, e mais uma vez em coletividade refletimos sobres experiências diaspóricas de mulheres rezadeiras que, ao migrarem do Nordeste brasileiro para a "Amazônia Bragantina", no Estado do Pará, a partir da década de 1950, tiveram suas vidas marcadas pelo processo de iniciação junto a entidades da encantaria brasileira (PRANDI, 2006). Em viagens noturnas a cemitérios, transfigurações, transportes físicos, vidências e andanças em corpos de animais, ventos e águas, essas rezadeiras revisitaram "mundos" e "tempos" imemoriais, passando a dialogar com pajés e "poderosos" rezadores do Maranhão, Paraíba, Piauí e Ceará, deixando ver pessoas e encantados em outros sentidos de deslocamento.

A crença na capacidade das entidades de acompanhar as pessoas detentoras do "dom de rezar" até o Pará, bem como de transitarem continuamente nesses locais, nomadizando-se (DELEUZE; GUATTARI, 1995) entre o "lá" e o "aqui", constitui o fenômeno da "diáspora dos encantados" (BRAH, 2011; HALL, 2003). Defendemos que "a convivência com essas mulheres ensina, entre outros aspectos, a defender concepções de encontros e deslocamentos de culturas que percebam a alteridade radical da cosmologia das ciências humanas, mesmo quando esta se crê fielmente situada em lugares de partida, movimentos de passagem ou chegada, esquecendo, muitas vezes, que se trata não de lugar, mas de trânsitos materiais e simbólicos" (SILVA e SARRAF-PACHECO, 2015).

Nesta viagem em busca das escritas de historiadores e antropólogos sobre ameríndios e africanos em zonas de intersecção, um dos primeiros trabalhos que segue na contramão da divisão desses mundos é o clássico e atual estudo de Roger Bastide “Américas Negras" de 1967. Conforme ensina Arruti (2001, p. 217), o pesquisador "aponta para a importância das trocas entre negros e indígenas na conformação de todo um tipo de cultura americana".

A escolha pela categoria afroindígena procura valorizar o ângulo dos marajoaras nas relações estabelecidas com colonizadores europeus e ibéricos, religiosos e outros sujeitos, tanto no período colonial, quanto em tempos contemporâneos. Inspirado em Deleuze e Guatarri (1995), Mignolo (2003), Roy Wagner (2012), Goldman (2014) e Silva (2015), defendo a potência, criatividade e crítica que a categoria afroindígena carrega para se contrapor a gramáticas eurocentradas e exógenas de nominação do "outro" como tapuio, curiboca, cafuzo ou mesmo caboclo, os quais, em ângulo exógeno, desqualificam, silenciam 
ou essencializam processos de identificação das populações amazônicas e marajoaras (GILROY, 2001).

\section{Repertórios de Saberes}

Para captar repertórios de narrativas, saberes e práticas de religiosidades de matriz afroindígena nos romances Chove nos Campos de Cachoeira, Marajó, Três Casas e Um Rio e Ribanceira de Dalcídio Jurandir, embarcamos na canoa da Cartografia. Nossa compreensão de cartografia caminha na contramão da cartografia moderna dual que criou linhas abissais e excluiu do direito à memória o subalterno e o ilegítimo, denunciada por Boaventura Santos (2010). Nos orientaremos por compreensões de Deleuze e Guattari (1995), Boaventura Santos (2002), Martín-Barbero (2004) e Glissant (2005). Sobre o princípio da cartografia, Deleuze e Guattari (1995, p. 22), assinalaram que o mapa possibilita múltiplas dimensões e aberturas. "Ele pode ser rasgado, revertido, adaptar-se a montagens de qualquer natureza, ser preparado por um indivíduo, um grupo, uma formação social (...). Uma das características mais importantes do rizoma talvez seja a de ter sempre múltiplas entradas”.

Na perspectiva de Boaventura Santos (2002) a cartografia revela múltiplos campos do saber que estruturam representações sobre a realidade social. Em Martín-Barbero (2004, p. 13) são "mapas cognitivos que traduzem outras figuras como a do arquipélago, desprovidas de fronteiras que os una. Com isso, o continente se desagrega em ilhas múltiplas e diversas, que se interconectam”. Já em Glissant (2005, p. 54) sob a metáfora do rizoma, a cartografia se faz dentro do "pensamento arquipélago, não sistemático, indutivo, que explora o imprevisto da totalidade-mundo, e que sintoniza, harmoniza a escrita à oralidade, e a oralidade à escrita”, a literatura à religião, e a religião à literatura, assim como indígenas de africanos.

Investigar dimensões do sagrado afroindígena em estéticas, poéticas, escritas e oralidades politicamente comprometida de Dalcídio Jurandir pelo universo da cartografia permite ampliar as experiências de "namoro entre religião e literatura" (CANTARELA, 2012b, p. 5). Por meio do mapeamento e interpretação de enunciados que trazem o mundo das religiões de matriz oral afroindígena nessas escrituras e oralidades de Marajó, a cartografia gesta conhecimentos nas interfaces de teorias nômades que combatem convenções do pensamento moderno. Para este campo, religião e literatura, sagrado e profano e oral e letrado expressam múltiplas relações, saberes e práticas locais que não são puras, pois tradições são sempre reinventadas e as etnias historicamente misturadas. 
Dalcídio Jurandir em Marajó visibiliza recriações do diálogo inter-religioso, explorando representações simbólicas em gestos e palavras no modo como os personagens procuram resolver problemas cotidianos.

- Vocês são uns curados, seus diabos!

Pedia defumação, ia ouvir lições de seu Felipe, usava quanto amuleto havia para caçador e nem um periquito por desgraça.

- Aposto que esses cachorros têm culpa. São empanemados. Mulher prenha comeu embiara deles, aposto (JURANDIR, 1992, p. 32-33).

Em Três Casas e Um Rio, "essência de tajás, de mel e bênçãos de Nossa Senhora, banha de algum peixe misterioso, óleo de misteriosa árvore, para curar, de súbito, aquelas queimaduras que doíam mais em Alfredo do que na própria irmã” (JURANDIR, 1994, p.18), recompõem a perene preocupação das re-existências marajoaras para cuidar do corpo e da alma orientados pela crença em santos, encantados, orixás, plantas, animais.

Apreendendo a literatura como uma produção do mundo da arte e da linguagem criadora de sentidos compartilhados na compreensão da vida em sociedade, nessa cartografia literária poderemos dizer que "o universo particular das tradições religiosas e das espiritualidades não se estabelece fora da linguagem; e que o fenômeno religioso pode ser mais bem compreendido quando situado no conjunto das outras manifestações culturais, incluindo as expressões do mundo da arte" (CANTARELA, 2014, p. 1229). Em outra direção, Dalcídio aliando realidade e ficção, documentação e criação literária procurou "evocar os fatos mais significativos através da ordem casual de rememorações espontâneas, que são inseridas na narrativa em forma de fragmentos" (BOLLE, 2011, p. 45).

No romance Chove nos Campos de Cachoeira, por exemplo, Dona Gemi "acostumada a curar doença de toda gente" (JURANDIR, 1995, p. 28), experiente em dar passe e benzer a população, opera com saberes das práticas de cura dos mundos cruzados afroindígena, como a realização de "chá de cana roxa pros rins" (p. 24) de Eutanázio, "homem magro e feio" (p. 27) carcomido por doença incurável que a levará à morte ao final do enredo romanesco.

Em Três Casas e Um Rio, para o menino Alfredo "o espantalho contra as mortes era sua mãe que sabia proteger o chalé. Via naqueles braços um poder de curar que não via em outras mulheres nem nos médicos lá em Belém, ou que passavam, tão raramente, nas lanças dos fazendeiros" (JURANDIR, 1994, p. 67). Em cenário anterior, Alfredo recria Irene vestida como "uma das donzelas encantadas do lago, de que falavam os pescadores, nas madrugadas lentas de tarrafeação e linha n'água. Talvez se preparasse ela para o baile no fundo, onde 
clara, a moça afogada no Araquiçaua, também dançaria, com um colar de goiabas maduras no pescoço". (p. 9).

O amplo repertório do mundo da encantaria afroindígena marajoara adensa-se e cruza com a complexa saga da vida na região em diferentes passagens de Três Casas em Um Rio. Em um dos questionamentos, retratando o tema do desviver, abordado por Edilson Pantoja da Silva (2015), emerge um questionamento cruzando a infância pobre, desvalida e faminta e o viver subterrâneo. "Não seriam aquelas crianças da rua de baixo, agora anjos não do céu, mas do fundo, que disputavam com os peixes as sobras de comida e as linhas atiradas das janelas do promotor público, do Salu, da Lucíola, do chalé? (JURANDIR, 1994, p. 17).

Personagem emblemática nos romances dalcidiano é D. Amélia, a mãe negra de Alfredo, o personagem central do Ciclo do Extremo Norte, com exceção do romance Marajó. Amélia é detentora de múltiplos saberes e fazeres orais capaz de hibridizar mitos e ritos do cristianismo, da pajelança e do candomblé, os quais, do ponto de vista subalterno, conforma o rico acervo de crenças das religiões de matriz afroindígena. "A tradição oral não apenas enriquece como funda e dá vitalidade à escrita literária africana”, assinala Cantarela (2012a, p. 137).

Em Três Casas e Um Rio (1994), durante o espetáculo de apresentação dos bois Garantido e Caprichoso em Cachoeira do Arari, D. Amélia entrou em transe. Aproveitando o intervalo da comédia, no salão de terra batida, teto de palha, lamparina de pavios enormes nos esteios, e enquanto o dono da casa servia café e cachaça aos brincantes, Dalcídio narra que a mãe negra, subitamente, apanhou o maracá de um índio, arrancou dos ombros de uma cabocla um pano azul, enfaixou a cintura e surgiu no meio do salão, cantando e dançando, em passo lento.

A sonoridade da cantoria, a performance e a voz de dona Amélia fizeram Alfredo abandonar sua súbita cólera e vergonha, ao ver a mãe sozinha no salão interpretando aquele desconhecido papel. Inspirada em meio a palmas que nasciam do salão, depois de consertar a garganta, em comunicação gestual para o violão, a personagem conduziu os espectadores para outros universos de práticas culturais afroindígenas nos espaços marajoaras.

Os elementos expressos, nestas cantorias e dançares, correspondem tanto às características do lundu, quanto aos cantos de encantarias em religiões afro-brasileiras. As referências ao mar e a areia no canto de D. Amélia, constantes em hinos de liturgias incorporativas, recompõem polos de partidas e chegadas e podem ainda situar memórias negras em diáspora, que deixando portos africanos, entraram em rotas para alçar portos e praias brasileiras, amazônicas e marajoaras. Esse canto tem um lugar especial no ritual de 
incorporação, pois se refere à partida ou despedida da entidade do seu receptor, "cavalo" como se diz no candomblé ou "aparelho", como em rituais da floresta praticados por benzedores marajoaras.

Personagens negras e negros com saberes, crenças e práticas afroindígenas reconstituem um Marajó de profundas mestiçagem e zonas de contato. Em Três Casas e Um Rio, Dalcídio talha com histórias profundas a trajetória, as lutas e astúcias contra a dominação de si por parte do negro Sebastião, irmão de dona Amélia, tio de Alfredo. Em uma das passagens, ele revela ao menino: “ - Sou curado, meu sobrinho. Não contou para não parecer pavulagem, que, ao matar uma sucuriju, tira sempre da cobra um pouco de banha cura e come" (JURANDIR, 1994, p. 85).

A chegada de Sebastião em Cachoeira do Arari adensava os burburinhos do povoado. As vizinhas, vira e mexe, "vinham dizer a d. Amélia que Sebastião, embora negro-negro como a ave japu, mundiava as moças que caíam de olhos fechados no peito dele”. Uma das personagens procurou explicar sobre o poder sedutor do negro: “- Foi ferroado pela formiga taoca, d. Amélia. Por isso atrai mulher" (JURANDIR, 1994, p. 86).

\section{Considerações Finais}

A proposta de cartografar repertórios de saberes e práticas de cura em romances dalcidianos ambientados na Amazônia Marajoara para explorar sinais de religiosidades afroindígenas é um desafio inesgotável. A cada leitura dos romances torna-se visível como humano e não-humano, a vida e a morte se atravessam nos rituais da vida cotidiana. Edilson Pantoja da Silva (2015) ao mapear e explorar a temática do desviver, do sofrimento, do pessimismo, fortemente presentes no ciclo do extremo-norte de Dalcídio Jurandir, assinala que, ao fim e ao cabo, o realismo literário frente às estruturas de dominação que conformam a existência humana na região desvela seu outro lado, jamais esquecido pelo autor - a esperança.

Homem da escrita, e comprometido com a esperança de dias melhores, tornou-a, nas diversas formas com que a usou - romance, etnografia e reportagem instrumento de denúncia, de visibilidade do "desviver" amazônico. Daí o referido tom. Seus romances e reportagens retratam o sofrimento sem firulas, sem enfeites, soluções falsas. Usam tintas da realidade para, ela mesma, denunciar, mostrar chamar a atenção para o sofrimento, a ver se alcançava solução algum dia. Ato de esperança (SILVA, 2015, p. 452). 
Os repertórios de saberes que articulam práticas nativas, colonizadoras e diaspóricas, interpretadas sob o ângulo da recriação e reafirmação de identidades indígenas, afromarajoaras e de seus descendentes permitem assinalar, baseados em Stuart Hall (2003), que continuamos em luta irregular, desigual e imprevisível com os grupos de poder, cujas vitórias e derrotadas não podem ser quantificadas, mas profundamente sentidas. Se a cultura da morte se alastra, vozes da vida mostram sua cara. Portanto, mapear saberes tradicionais e sondar a perene memória que o atualiza é sinal de que as batalhas da memória de populações afroindígenas seguem em curso.

\section{Referências}

ANTONACCI, Maria Antonieta. Tradições de oralidade, escritura e iconografia na literatura de folhetos: nordeste do Brasil, 1890/1940. Projeto História, São Paulo, v. 22, PUCSP/EDUC, p. 105-138, junho, 2001.

ARRUTI, José Maurício Andion. Agenciamentos Políticos da "Mistura": identificação étnica e segmentação negro-indígena entre os Pankararú e os Xocó. Estudos Afro-Asiáticos, n. 2, p. 215-254, 2010.

BASTIDE, Roger. As Américas negras. São Paulo: EDUSP, 1974 [1967].

BASTIDE, Roger. "La rencontre des dieux africains et des esprits indiens". Afro-Ásia, v. 12, p. 31-45, 1976 [1973].

BOLLE, Willi. A escrita da história de Marajó, em Dalcídio Jurandir. Novos Cadernos NAEA, v. 14, n. 1, p. 43-78, jun. 2011.

BOLLE, Willi. Ler é Navegar. In: NUNES, Paulo. Aquanarrativa: uma leitura de Chove nos Campos de Cachoeira, de Dalcídio Jurandir. Belém: Unama, 2001, p. 3-4.

BRAH, A. Cartografías de la diáspora: identidades en cuestión. Madrid: Traficantes de Sueños, 2011.

BRANDÃO, Daniela dos S. "Belém do Grão-Pará: análise dos aspectos religiosa na literatura de Dalcídio Jurandir". Projeto de Pesquisa. Programa de Pós-Graduação em Ciências da Religião, Universidade do Estado do Pará, Belém-PA, 2016.

CANDIDO, Antônio. Formação da Literatura Brasileira. 2 v. Belo Horizonte: Itatiaia, 1981.

CANTARELA, Antonio Geraldo. A pesquisa em teopoética no Brasil: pesquisadores e produção bibliográfica. Horizonte, Belo Horizonte, v. 12, p. 1228-1251, 2014.

CANTARELA, Antonio Geraldo. Apresentação - Dossiê: Religião e Literatura. Horizonte, Belo Horizonte, v. 10, n. 25 p. 5-7, jan./mar. 2012b. 
CANTARELA, Antonio Geraldo. A voz reinventada da tradição: ritos iniciáticos na obra de Mia Couto. Horizonte, Belo Horizonte, v. 10, p. 136-156, $2012 \mathrm{a}$.

CERTEAU, Michel. A invenção do cotidiano. 3. ed. Petrópolis, RJ: Vozes, 1998.

CONCEIÇÃO, Douglas. Teologias e Literaturas 3. Aspectos religiosos em Machado de Assis. São Paulo: Fonte Editorial, 2013.

CONCEIÇÃO, Douglas Rodrigues. Expressando a fé: experiência religiosa, testemunho autobiográfico e religioso na poesia de Adélia Prado. Soletras, v. 1, p. 38-52, 2012.

DELEUZE, G. e GUATTARI, F. Mil Plâtos: capitalismo e esquizofrenia. RJ: Ed. 34, (1995).

FURTADO, Marli Tereza. Dalcídio Jurandir e o romance de 30 ou um autor de 30 publicado em 40. Teresa - Revista de Literatura Brasileira (USP), v. 16, p. 191-204, 2015.

GALVÃO, Walnice Nogueira. Hibridismo religioso na literatura brasileira. Imaginário, v.12 n.12, São Paulo, p. 1-8, jun. 2006.

GANDON, Tania Almeida. O índio e o negro: uma relação legendária. Afro-Ásia, n. 19/20, p. 135-164, 1997.

GLISSANT, Édouard. Introdução a uma poética da diversidade. Tradução de Enilce do Carmo Albergaria Rocha. Juiz de Fora: Editora UFJF, 2005.

GOLDMAN, Marcio. Quinhentos Anos de Contato: Por uma Teoria Etnográfica da (Contra)Mestiçagem. Mana (UFRJ. Impresso), v. 21, p. 641-659, 2015.

GILROY, Paul. O Atlântico Negro: modernidade e dupla consciência. Tradução de Cid Kinipel Moreira. São Paulo: Editora 34; Rio de Janeiro: Universidade Cândido Mendes;

Centro de Estudos Afro-Asiáticos, 2001.

HALL, Stuart. Da Diáspora: identidades e mediações culturais. Tradução Adelaine La Guardiã Resende... [et. al]. Belo Horizonte: Editora UFMG, 2003.

HAMPATÉ BÂ, A. A tradição viva. In: KI-ZERBO, J. (editor). Metodologia e pré-história da África. Tradução MEC. 3. Ed. - São Paulo: Cortez; Brasília: UNESCO, 2011, p. 167-212.

HOGGART, Richard. As utilizações da cultura. Aspectos da vida cultural da classe trabalhadora. Lisboa: Ed. Presença, v. 1 e 2, 1973.

TILLICH, Paul. Dinâmica da fé. 6. ed. São Leopoldo, RS: Sinodal, 2001.

JURANDIR, Dalcídio. Chove nos campos de Cachoeira. 4. ed. Belém: CEJUP, 1995 [1941].

JURANDIR, Dalcídio. Marajó. 3. ed. Belém: CEJUP, 1992 [1947].

JURANDIR, Dalcídio. Três casas e um Rio. 3. ed. Belém: CEJUP, 1994 [1958].

JURANDIR, Dalcídio. Ribanceira. Rio de Janeiro: Record, 1978. 
LANDER, Edgardo (Org.) A colonialidade do saber: eurocentrismo e ciências sociais perspectivas latino-americanas. Tradução Júlio César Casarin Barroso Silva. Buenos Aires: Consejo Latinoamericano de Ciencias Sociales - CLACSO, 2005.

LOUREIRO, Violeta Refkalesk. Resenha de Três Casas e um Rio de Dalcídio Jurandir. Disponível em https://rafaelkafka2011.wordpress.com/2015/11/02/resenha-de-tres-casas-eum-rio-de-dalcidio-jurandir/. Acesso em 20/08/2017.

MAGAlHÃES, Antonio. Deus no Espelho das Palavras. Teologia e literatura em diálogo. $2^{\text {a }}$ ed. São Paulo: Paulinas, 2009.

MARTÍN-BARBERO, Jesus. Dos meios às mediações: comunicação, cultura e hegemonia. 2. edição. Rio de Janeiro: Editora UFRJ, 2001.

MAUÉS, Raymundo Heraldo e VILLACORTA, Gisela Macambira (orgs.). Pajelanças e Religiões Africanas na Amazônia. Belém: EDUFPA, 2008.

MAUÉS, Raymundo Heraldo. Padres, pajés, santos e festas: catolicismo popular e controle eclesiástico. Belém: CEJUP, 1995.

MIGNOLO, Walter. Desafios Decoloniais hoje. Epistemologias do Sul, Foz do Iguaçu/PR, v. 1 n. 1, 2017, p. 12-32.

MIGNOLO, Walter. Desobediência Epistêmica: A opção Descolonial e o significado de Identidade em Política. Cadernos de Letras da UFF - Dossiê: Literatura, língua e identidade, no 34, p. 287-324, 2008.

MIGNOLO, Walter D. Histórias Locais/Projetos Globais: colonialidade, saberes subalternos e pensamento limitar. Tradução de Solange Ribeiro de Oliveira. Belo Horizonte: UFMG, 2003.

PRANDI, Reginaldo (Org.). Encantaria brasileira: o livro dos mestres, caboclos e encantados. Rio de Janeiro: Pallas, 2006.

PRATT, Mary Louise. Os olhos do Império: relatos de viagem e transculturação. Tradução de Jézio Hernani Bonfim Gutieerre. Bauru: EDUSC, 1999.

PEREIRA, Manuel Nunes. Negros Escravos na Amazônia. Anais do X Congresso Brasileiro de Geografia, 1944. Rio de Janeiro: IBGE, 1952, V. 3, p. 153-185.

PERLIN, Sandra Terezinha. Do dilúvio à vida: chove nos campos de cachoeira. Dissertação (Mestrado). Programa de Pós-Graduação em Ciências da Religião, UEPA, Belém-PA, 2013.

PRESSLER, Gunter Karl. O Maior Romancista da Amazônia - Dalcídio Jurandir - e o Mundo do Arquipélago de Marajó. In: BOLLE, Willi; CASTRO, Edna; VEJMELKA, Marcel (Orgs.) Amazônia. Região Universal e Teatro do Mundo. São Paulo: Globo, 2010, p. 235-259.

SALLES, Vicente. O negro no Pará sob o regime da escravidão. 3. ed. Rev. Ampl. Belém: IAP; Programa Raízes, 2005 [1971]. 
SANTOS, Boaventura de Sousa. A crítica da razão indolente: contra o desperdício da experiência. 4. Ed. São Paulo: Cortez, 2002.

SANTOS, Boaventura de Sousa. Para além do Pensamento Abissal: das linhas globais a uma ecologia de saberes. SANTOS, Boaventura de Sousa e MENEZES, Maria Paula (Orgs.). Epistemologias do Sul. São Paulo: Cortez, 2010, p. 31-83.

SARRAF-PACHECO, Agenor. Cosmologias Afroindígenas na Amazônia Marajoara. Projeto História, São Paulo, n. 44, jun. p. 197-226, 2012.

SARRAF-PACHECO, Agenor. Encantarias Afroindígenas na Amazônia Marajoara: Narrativas, Praticas de Cura e (In)tolerâncias Religiosas. Horizonte, Belo Horizonte, v. 08, p. 88-108, 2010.

SARRAF-PACHECO, Agenor. À Margem dos Marajós: memórias em fronteiras na nascente "Cidade-Floresta" Melgaço-PA. Dissertação (Mestrado). Programa de Estudos PósGraduados em História Social, PUC-SP, São Paulo, 2005.

SARRAF-PACHECO, Agenor. En El Corazón de La Amazonía: identidades, saberes e religiosidades no Regime das Águas Marajoaras. Tese (Doutorado), Programa de Estudos Pós-Graduados em História Social, PUC-SP, São Paulo, 2009.

SCHWARTZ, Stuart B. Tapanhuns, Negros da Terra e Curibocas: causas comuns e confrontos entre negros e indígenas. Afro-Ásia, n. 29/30, 2003, p. 13-40.

SERRY, Hervé. Literatura e catolicismo na França (1880-1914) contribuição a uma sociohistória da crença. Tempo Social, USP, p. 129-152, jun. 2004.

SILVA, Jefferson Cesar Reis da. "DO MEDO À FÉ: Um Ensaio da Obra Cordelística Chacina de Goianésia do Pará - Romaria da Libertação”. In: Amazônia(s): diálogos socioculturais e socioeducativos. Curitiba: Prisma, 2018 (no prelo)

SILVA FILHO, Fernando A. de O. e. Um Estranho no Espelho: construção e reprodução do imaginário sobre o caboclo na Amazônia, envolvendo a dicotomia entre bárbaros e civilizados. Tese (Doutorado). Programa de Pós-Graduação em Ciências Sociais, UFPA, Belém-PA, 2011.

SILVA, J. P. da; SARRAF-PACHECO, A. Tupinambá, Indígena ou Afroindígena? Identidades, Poderes e Cosmologias no Marajó das Florestas. Anais do X Jornadas Andinas de Literatura Latinoamericana, Cali-Colômbia: Ed. da Universidad del Valle, 2012, p. 78-90.

SILVA, Douglas Pereira e. Religião e Literatura: possíveis aproximações. Anais do Congresso ANPTECRE, v. 05, 2015, p. 1-8.

SILVA, Edilson Pantoja da. Filosofia, antropologia e reportagem em ribanceira: Considerações sobre o desviver na Amazônia de Dalcídio Jurandir. Amazônica - Revista de Antropologia (Online), v. 7, n. 2, p. 428-454, 2015.

SILVA, Eli Brandão. Resignação de Jó em "Ritual de Danação", de Gilvan Lemos. In: FERRAZ, et al. Deuses em Poéticas. Estudo de Literatura e Teologia. Belém: EDUEP, 2008. 
SILVA, Jerônimo Silva e SARRAF-PACHECO, Agenor. Oralidades em tempos de possessões afroindígenas. História Oral (Rio de Janeiro), v. 15, p. 167-192, 2012.

SILVA, Jerônimo da Silva e. Cartografia de Afetos na Encantaria: narrativas de mestre da Amazônia Bragantina. Tese (Doutorado). Programa de Pós-Graduação em Antropologia, UFPA, Belém-PA, 2014.

SILVA, Jerônimo Silva e SARRAF-PACHECO, Agenor. Diásporas de encantados na Amazônia Bragantina. Horizontes Antropológicos (Online), v. 21, p. 129-156, 2015.

SPERBER, Suzi Frankl. (Org.) Presença do sagrado na literatura: questões teóricas e de hermenêutica. Campinas: Publiel; Unicamp, 2011.

VANZOLINI, Marina. Daquilo que não se sabe bem o que é: a indeterminação como poder nos mundos afroindígenas. Cadernos de Campo, São Paulo, n. 23, p. 271-285, 2014.

VIDAL, Rodrigo. A cidade e seu território através do ordenamento urbano em Santiago do Chile. Projeto História, n. 14, São Paulo, PUC, p. 183-215, fev. 1997.

WAGNER, Roy. A Invenção da Cultura. Trad. Marcela Coelho de Souza e Alexandre Morales. São Paulo: Cosac NaifyPortátil, 2012.

WILLIAMS, Raymond. Marxismo e literatura. Rio de Janeiro: Zahar Editora, 1979. 